\title{
Identification of the Organism and Some Conditions of Peptidoglutaminase Formation
}

\author{
Mamoru KIKUCHI and Kenji SaKaguCHI* \\ Noda Institute for Scientific Research, Noda-shi, Chiba-ken, Japan \\ Received May 31, 1972
}

\begin{abstract}
A peptidoglutaminase activity in microorganisms was detected using carbobenzoxy-Lglutamine or tertiary-amyloxycarbonyl-L-glutaminyl-I-proline as substrate. By screening, an organism which produces a relatively large amount of peptidoglutaminase was isolated from soil. The organism was identified as Bacillus circulans. The highest enzyme formation by the bacterium occurred during stationary growth phase in the basal medium containing lactose $(0.5 \%)$ and polypepton $(1 \%)$.
\end{abstract}

Though L-glutaminase (EC 3.5.1.2.) has been widely found in animals, plants and microorganisms, their substrate specificities are restricted to L-glutamine or the derivatives. ${ }^{1 \sim 4}$ Mycek and Waelsch, ${ }^{5}$ Folk and Cole ${ }^{6 /}$ have shown that a transglutaminase from guinea pig liver catalyzes the deamidation of glutamine in protein or peptide. However, the enzymic activity has not yet been detected other than from the animal tissue. Therefore, an attempt to seek the enzymic activity from microbial origin has been made. CBZ-L-glutamine* and $t$-AOC-L-glutaminyl-L-proline* were used as the substrates for the screening of the enzymic activity for the reason that they are resistant to hydrolysis with proteases, peptidases and deamidation of already known L-glutaminases. By the screening of many strains of fungi, actinomycetes, yeasts and bacteria which were stocked in our culture collection and isolated from soils, an organism having a relatively high deamidating activity of the substrates was found. The partial purification and some properties of the enzyme were reported in the previous paper, and this enzyme was designated as peptidoglutaminase because of its substrate specificity. The present communication deals with the

* Present address: Mitsubishi-Kasei Institute of Life Science, c/o Mitsubishi Chemical Industry, Limited, Marunouchi, Chiyodaku, Tokyo, Japan.

** The abbreviations used are: CBZ, carbobenzoxy; t-AOC, tert-amyloxycarbonyl. consequence of the screening, the identification of the microorganism and some conditions for peptidoglutaminase formation using this strain.

\section{MATERIALS AND METHODS}

Materials. CBZ-L-glutamic acid, CBZ-L-glutamine, $t$-AOC-L-glutaminyl-L-proline, and $t$-AOC-L-glutamylL-proline were supplied by the Protein Research Foundation in the Institute for Protein Research, Osaka, Osaka University. The synthesis of CBZ-L-glutaminylL-proline was appeared in previous paper." Other materials used were the best available commercial products.

Media and cultivation. Three hundred, 133, 156 and 66 strains of actinomycetes, bacteria, fungi and yeast respectively, in our culture collection were tested. They were cultivated by shaking in the following media at $30^{\circ} \mathrm{C}$ for $2 \sim 7$ days. A-medium for actinomycetes consisted of $10 \%$ glucose, $2 \%$ polypepton, $1 \%$ beef extract, $1 \%$ yeast extract $(\mathrm{pH} 7.2)$. B-medium for bacteria; $1 \%$ polypepton, $0.5 \%$ lactose, $0.3 \%$ yeast extract, $0.025 \% \mathrm{MgSO}_{4} \cdot 7 \mathrm{H}_{2} \mathrm{O}, 0.001 \% \mathrm{FeSO}_{4} \cdot 7 \mathrm{H}_{2} \mathrm{O}$, $0.025 \% \quad \mathrm{KH}_{2} \mathrm{PO}_{4}, 0.2 \% \quad \mathrm{Na}_{2} \mathrm{HPO}_{4} \cdot 12 \mathrm{H}_{2} \mathrm{O} \quad(\mathrm{pH} 7.2)$. C-medium for fungi; $3 \%$ skim milk, $3 \%$ glucose. Dmedium for yeast; $10 \%$ glucose, $0.5 \%$ polypepton, $0.3 \%$ yeast extract, $0.1 \% \mathrm{KH}_{2} \mathrm{PO}_{4}, 0.01 \% \mathrm{CaCl}_{2} \cdot 2 \mathrm{H}_{2} \mathrm{O}$, $0.01 \% \mathrm{NaCl}, 0.05 \% \mathrm{MgSO}_{4} \cdot 7 \mathrm{H}_{2} \mathrm{O}(\mathrm{pH} 7.0)$.

Microorganisms were isolated from soil by the following procedure. Each about $0.1 \mathrm{~g}$ of soil samples obtained from such places as field, forest, and green of Kyushu district was suspended in $1 \mathrm{ml}$ of medium B containing $5 \mathrm{~mm} t$-AOC-L-glutaminyl-L-proline, and then cultivated with shaking for $3 \sim 7$ days. After an aliquot of the broth was suspended in $5 \mathrm{ml}$ of sterilized water, a drop of the suspension was spread 
on the agar plate of B-medium by the ordinary way. The colonies after $48 \mathrm{hr}$ cultivation at $30^{\circ} \mathrm{C}$ were inoculated into the liquid $\mathrm{B}$-medium.

Detection of peptidoglutaminase activity. Peptidoglutaminase activity was roughly examined by two methods.

1) Detection of deamidated product by thin-layer chromatography. After the incubation of the reaction mixture composed of $0.25 \mathrm{ml}$ of $0.2 \mathrm{M}$ buffer (phosphate buffer pH 7.5) containing $5 \mathrm{~mm} \mathrm{CBZ-L-}$ glutamine or $t$-AOC-L-glutaminyl-L-proline and $0.25 \mathrm{ml}$ of the cultured broth in a final volume of $0.5 \mathrm{ml}$ for $2 \mathrm{hr}$ at $30^{\circ} \mathrm{C}$, a small amount of the mixture was spotted on thin-layer of silica-gel (Kieselgel G Nach Stahl, Merck), and developed using a solvent system of butanol-acetic acid-water $(4: 1: 1)$. The enzyme activity was roughly detected from a red spot of CBZ-Lglutamic acid or $t$-AOC-L-glutamyl-L-proline stained by ninhydrin reagent after the treatment with $\mathrm{HBr}$ solution on the thin-layer plate, which was arised from CBZ-L-glutamine or $t$-AOC-L-glutaminyl-L-proline, respectively, by the enzyme.

2) Hydroxamate formation. Colorimetric determination of hydroxamates was performed by the method of Lipmann and Tuttle. ${ }^{8}$ After the incubation of the reaction mixture composed of $5 \mathrm{~mm} \mathrm{CBZ-glutamine}$ or $t$-AOC-L-glutaminyl-L-proline, $100 \mathrm{~mm}$ hydroxylamine neutralized, $100 \mathrm{~mm}$ phosphate buffer $(\mathrm{pH} 7.5)$, and $0.5 \mathrm{ml}$ of the cultured broth in a final volume of $1.0 \mathrm{ml}$ for $2 \mathrm{hr}$ at $30^{\circ} \mathrm{C}, 0.9 \mathrm{ml}$ of ferric chloride-trichloroacetic acid reagent was added to the mixture and centrifuged for $15 \mathrm{~min}$ at $3000 \mathrm{rpm}$. The absorbance of the clear supernatant obtained was measured at $525 \mathrm{~nm}$.

\section{Peptidoglutaminase formation by $B$. circulans.}

1) Culture. The composition of basal medium was as follows: $0.3 \%$ yeast extract, $0.025 \% \mathrm{MgSO}_{4}$. $7 \mathrm{H}_{2} \mathrm{O}, 0.001 \% \mathrm{FeSO}_{4} \cdot 7 \mathrm{H}_{2} \mathrm{O}, 0.025 \% \mathrm{KH}_{2} \mathrm{PO}_{4}$, and $0.17 \% \mathrm{Na}_{2} \mathrm{HPO}_{4} \cdot 12 \mathrm{H}_{2} \mathrm{O}, \mathrm{pH} 7.2$. Fifteen $\mathrm{ml}$ of basal medium containing carbon and nitrogen sources was placed in a $150-\mathrm{ml}$ shaking flask. After sterilization at $110^{\circ} \mathrm{C}$ for $10 \mathrm{~min}, 0.15 \mathrm{ml}$ of a seed culture which was precultured for $12 \mathrm{hr}$ in basal medium containing $0.5 \%$ polypepton and $0.1 \%$ lactose was inoculated to the flask except the experiment on the effect of nitrogen source. In the experiments on the effect of nitrogen source, growing cells were directly inoculated from the agar slant. The culture was carried out at $30^{\circ} \mathrm{C}$ on a reciprocal shaker operating at $120 \mathrm{rpm}$. Cell growth was determined with a Gilford 240 spectrophotometer or Klett-Summerson photoelectric colorimeter at $660 \mathrm{~nm}$.
2) Enzyme assay. Quantitative peptidoglutaminase activity was determined by liberation of ammonia from CBZ-L-glutamine, $t$-AOC-L-glutaminyl-L-proline and CBZ-L-glutaminyl-L-proline. The reaction mixture contained $10 \mu$ moles substrate, $40 \mu$ moles phosphate buffer ( $\mathrm{pH} 7.5$ ), and the culture broth in $1.0 \mathrm{ml}$. After incubation for $10 \mathrm{~min}$ at $30^{\circ} \mathrm{C}, 1.0 \mathrm{ml}$ of $10 \%$ trichloroacetic acid was added to the reaction mixture $(1.0 \mathrm{ml})$ and $\mathrm{pH}$ was adjusted to $6.0 \sim 6.5$ with $1 \mathrm{~N}$ $\mathrm{NaOH}$. Ammonia was determined by nesslerization of these samples after a modified Conway microdiffusion.9' One unit of peptidoglutaminase activity is defined as that which catalyzes the liberation of $1 \mu$ mole of ammonia from glutaminyl peptide per $1 \mathrm{~min}$ at $30^{\circ} \mathrm{C}$. Peptidoglutaminase activity was also quantitatively determined by the above mentioned hydroxamate formation method.

\section{RESULTS AND DISCUSSION}

\section{Isolation of peptidoglutaminase producing strains}

It was found that some strains of bacteria, yeasts and fungi used here catalyzed the deamidation or hydroxamate formation with CBZ-L-glutamine. These strains are Bacillus circulans ATCC 9966, Cryptococcus albidus IAM 4830, Debaryomyces kloecheri NISL 3168, and Aspergillus japonicus NISL 1744, in which former two strains are active only to CBZ-Lglutamine and not to $t$-AOC-L-glutaminyl-Lproline, and latter two strains are active to both substrates. However, activities were not strong.

Then, an attempt was made to obtain microorganisms possessing strong activity for $t$ AOC-L-glutaminyl-L-proline from soils. As a result, one bacterial strain No 466 which was isolated from soil exhibited higher activities catalyzing deamidation of $t$-AOC-L-glutaminylL-proline and CBZ-L-glutamine and hydroxamate formation from both substrates than those in the strains tested so far.

\section{Determination of the bacterium, strain No 466}

Diagnostic tests were carried out according to the Manual of Microbiological Methods, ${ }^{10)}$ and then classified according to the Bergey's Manual of Determinative Bacteriology. ${ }^{11}$ 
Temperature for incubation was maintained at $30^{\circ} \mathrm{C}$ in most cases, except gelatin liquefaction test. The other tests were carried out in the usual way.

\section{The properties of strain No 466}

i) Microscopic observation. Rod shaped cells ( 0.4 to 0.8 by 2.2 to 4 microns) capable of producing endospores which are ellipsoidal and are located in the center of the cell. Sporangia definitely swollen. Motile by means of peritrichous flagella, and Gram negative (Fig. 1).

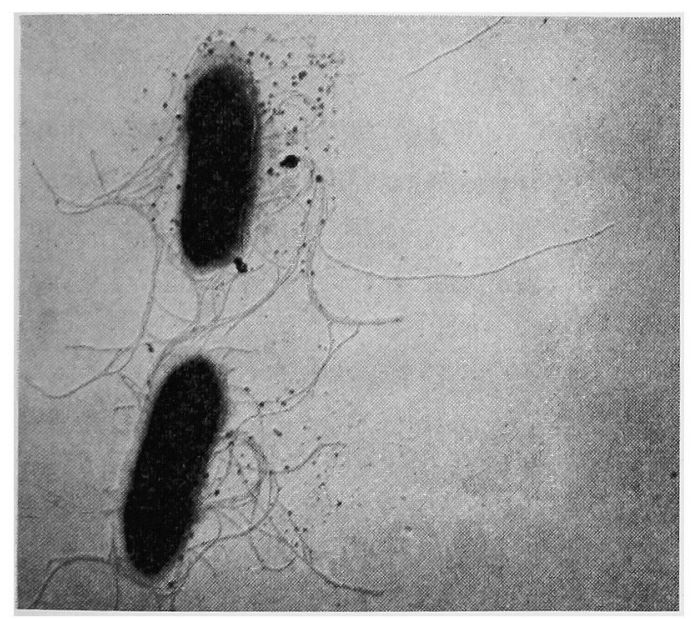

FIG. 1. Electron Micrograph of Strain No 466.

Nutrient broth agar containing $0.5 \%$ lactose, $\times 6000$.

ii) Cultural characteristics on various media.

Agar slants; Growth scant and thin.

Glucose-agar slant: Growth heavier than on agar, very gummy, opaque. No colouring matter formed in a medium.

Gelatin stab: Surface growth slightly, no liquefaction.

Nutrient broth: Slight growth.

$\mathrm{NaCl}$ broth: No growth in $5 \% \mathrm{NaCl}$.

iii) Physiological properties.

1. Litmus milk: Unchanged, no peptonization.

2. Catalase: Positive.
3. Indole is not produced.

4. Acid formation from carbohydrates: As shown in Table I, acid is produced from glucose, galactose, mannose, xylose, sucrose, dextrin, starch and lactose. In all cases gas formation is nor recognized.

5. Starch hydrolysis: Positive.

6. Voges-Proskauer test is negative.

7. Nitrates not reduced to nitrites.

8. Urease: Negative.

9. Reaction to free oxygen: Strictly aerobic.

10. Temperature relations: Optimum, about $30^{\circ} \mathrm{C}$, maximum at $40^{\circ} \mathrm{C}$.

11. Ammonia is slightly produced.

12. Hydrogen sulfide slightly produced.

13. pH Range: Growth, $\mathrm{pH} 5.0$ to 8.0.

14. Methyl red test is negative.

15. Source: Isolated from soil.

From the above experimental facts, No 466 strain was considered to belong to Bacillus

Table I. Acid Production from Carbohydrates By Strain No 466

\begin{tabular}{|c|c|c|}
\hline Carbohydrates & $\begin{array}{c}\text { Acid } \\
\text { production }\end{array}$ & $\begin{array}{l}\text { Gas in } \\
\text { pepton- } \\
\text { water }\end{array}$ \\
\hline Glucose & + & - \\
\hline Fructose & - & - \\
\hline Galactose & + & - \\
\hline Mannose & + & - \\
\hline Xylose & + & - \\
\hline Arabinose & - & - \\
\hline Sucrose & + & - \\
\hline Lactose & + & - \\
\hline Trehalose & - & - \\
\hline Raffinose & - & - \\
\hline Maltose & + & - \\
\hline Mannit & - & - \\
\hline Glycerin & - & - \\
\hline Dextrin & + & - \\
\hline Starch & + & - \\
\hline Inulin & - & - \\
\hline Glycogen & - & - \\
\hline Rhamnose & - & - \\
\hline Salicin & - & - \\
\hline$\alpha$-Methylglucoside & - & - \\
\hline Sorbit & - & - \\
\hline
\end{tabular}


Table II. Effect of Carbon Sources on the Enzyme Formation

\begin{tabular}{|c|c|c|c|c|c|c|}
\hline \multirow{3}{*}{ Carbon source } & \multicolumn{3}{|c|}{ 12-hr culture } & \multicolumn{3}{|c|}{ 24-hr culture } \\
\hline & \multirow{2}{*}{$\begin{array}{l}\text { Growth } \\
\text { (O.D.) }\end{array}$} & \multicolumn{2}{|c|}{ Activity on } & \multirow{2}{*}{$\begin{array}{l}\text { Growth } \\
\text { (O.D.) }\end{array}$} & \multicolumn{2}{|c|}{ Activity on } \\
\hline & & CBZ-L-Gln & $\begin{array}{l}\text { CBZ-L-Gln- } \\
\text { Pro }\end{array}$ & & CBZ-L-Gln & $\begin{array}{c}\text { CBZ-L-Gln- } \\
\text { Pro }\end{array}$ \\
\hline & \multicolumn{3}{|c|}{ units $/ \mathrm{ml}$ broth } & \multicolumn{3}{|c|}{ units $/ \mathrm{ml}$ broth } \\
\hline None & 0.16 & 0 & 0 & 0.19 & 0 & 0 \\
\hline Lactose & 2.75 & 0.312 & 0.334 & 1.95 & 0.388 & 0.428 \\
\hline Sucrose & 2.03 & 0.197 & 0.172 & 1.67 & 0.258 & 0.362 \\
\hline Maltose & 2.07 & 0.164 & 0.141 & 1.95 & 0.226 & 0.401 \\
\hline Galactose & 2.47 & 0.164 & 0.141 & 2.27 & 0.275 & 0.363 \\
\hline Starch & 2.58 & 0.386 & 0.327 & 2.58 & 0.582 & 0.425 \\
\hline Glucose & 1.60 & 0.023 & 0.008 & 0.95 & 0.024 & 0.011 \\
\hline Fructose & 2.06 & 0.019 & 0.030 & 1.88 & 0.012 & 0.029 \\
\hline
\end{tabular}

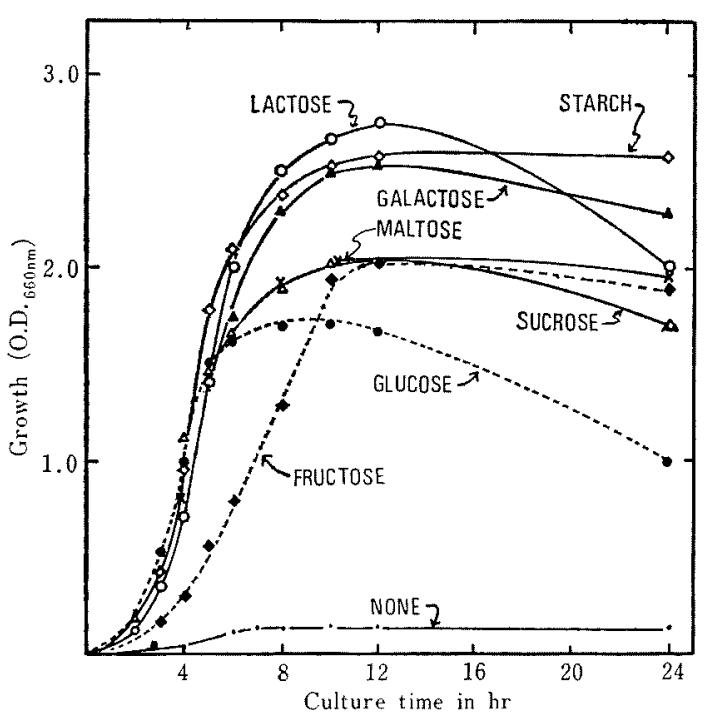

FIG. 2. Effects of Various Carbon Sources on Cell Growth.

$\bigcirc-0$, Lactose; --- Glucose; $-\diamond$, Starch; $\bullet--\bullet$, Fructose; $\triangle-\triangle$, Sucrose; $\Delta-\Delta$, Galactose; $\times-x$, Maltose; $-\cdot-\cdot-$, None.

circulans described in Bergey's Manual of Determinative Bacteriology 7th ed. There exist, however, some minor differences between No 466 strain and the description of $B$. circulans. No 466 strain does not require thiamine and biotin as essential factor for growth because this strain is able to grow in a minimum medium composed of $0.7 \%$ $\mathrm{KH}_{2} \mathrm{PO}_{4}, 0.3 \% \mathrm{~K}_{2} \mathrm{HPO}_{4}, 0.01 \% \mathrm{MgSO}_{4} \cdot 7 \mathrm{H}_{2} \mathrm{O}$, $0.1 \% \quad\left(\mathrm{NH}_{4}\right)_{2} \mathrm{SO}_{4}, \quad 0.001 \% \quad \mathrm{FeSO}_{4} \cdot 7 \mathrm{H}_{2} \mathrm{O}$, and $0.2 \%$ glucose, but utilized many kinds of sugars for growth as carbon source (Fig. 2).

III. Some factors for peptidoglutaminase formation

1) Effect of carbon sources. When polypepton used as nitrogen source, lactose, sucrose, maltose, starch, and galactose supported good growth and enzyme formation. On the contrary, glucose and fructose did not support enzyme formation (Fig. 2 and Table II). Figure 3 shows the effect of lactose concentration on peptidoglutaminase formation using $1 \%$ polypepton as nitrogen source.



FIG. 3. Effect of Lactose Concentration on Enzyme Formation.

Incubation was carried out for $24 \mathrm{hr}$ at $30^{\circ} \mathrm{C}$ using. $1 \%$ polypepton as a nitrogen source. Enzyme activity was presented as rate of hydroxamate formation. $x--x$, Growth; $O-O$, Enzyme activity of CBZ-Lglutamine; $\longrightarrow$, Enzyme activity to $t$-AOC-Lglutaminyl-L-proline; 
TABle III. EFFFCT OF VARIOUS NITROGEN SOURCES ON THE ENZYME Formation

\begin{tabular}{|c|c|c|c|c|}
\hline \multirow{3}{*}{$\begin{array}{l}\text { Nitrogen } \\
\text { source }\end{array}$} & \multirow{3}{*}{$\begin{array}{c}\text { Con- } \\
\text { centr- } \\
\text { ation } \\
(\%)\end{array}$} & \multirow{3}{*}{$\begin{array}{l}\text { Growth } \\
\text { (O.D.) }\end{array}$} & \multicolumn{2}{|c|}{ Enzyme activity } \\
\hline & & & $\begin{array}{l}\text { CBZ-L- } \\
\text { Gln }\end{array}$ & $\begin{array}{l}t-\mathrm{AOC}-\mathrm{L}- \\
\text { Gln-Pro }\end{array}$ \\
\hline & & & \multicolumn{2}{|c|}{ O.D. at $525 \mathrm{~nm}$} \\
\hline $\mathrm{NH}_{4} \mathrm{Cl}$ & 0.5 & 1.60 & 0.005 & 0.005 \\
\hline$\left(\mathrm{NH}_{4}\right)_{2} \mathrm{SO}_{4}$ & 0.5 & 1.80 & 0 & 0 \\
\hline $\mathrm{NaNO}_{3}$ & 0.5 & 1.87 & 0.024 & 0.014 \\
\hline Urea & 0.5 & 1.45 & 0.004 & 0 \\
\hline Na-glutamate & 0.5 & 2.02 & 0.010 & 0.105 \\
\hline Casamino acid & 1.0 & 1.60 & 0.025 & 0 \\
\hline Polypepton & 1.0 & 2.66 & 0.255 & 0.150 \\
\hline Trypton & 1.0 & 2.58 & 0.310 & 0.165 \\
\hline $\begin{array}{l}\mathrm{N}-\mathrm{Z} \text {-Amine } \\
\text { type-E }\end{array}$ & 1.0 & 2.46 & 0.260 & 0.125 \\
\hline Milk casein & 1.0 & $1.20^{a}$ & 0 & 0 \\
\hline
\end{tabular}

a) O.D. was measured after the $\mathrm{pH}$ of broth was adjusted to 8.0 .

Maximum activities were obtained at a concentration of $0.5 \%$, and the enzyme formation was gradually decreased by increasing the concentration of lactose, while the cell growth was scarcely changed.

2) Effect of nitrogen sources. Various kinds of nitrogen sources were tested for the enzyme formation (Table III). Inorganic nitrogen was a poor source for both growth and peptidoglutaminase formation even in the presence of $0.3 \%$ yeast extract. Casamino acid and milk casein were also poor nitrogen sources. On the contrary, polypepton, trypton and $\mathrm{N}$-Z-amine type-E which were proteolytic hydrolysates of casein supported good growth and enzyme formation. Figure 4 shows the effect of polypepton concentration of peptidoglutaminase formation using $0.5 \%$ lactose as carbon source. This result indicates that the enzyme formation was greatly affected by the concentration of polypepton, while the cell growth was not affected. Maximum activities were obtained at the concentration of $1 \%$ polypepton, but very poor at $2.5 \%$ or $5 \%$.

3) Time course of incubation. The growth curve and the enzyme production of $B$. circulans No 466 strain in the basal medium containing lactose $(0.5 \%)$ and polypepton

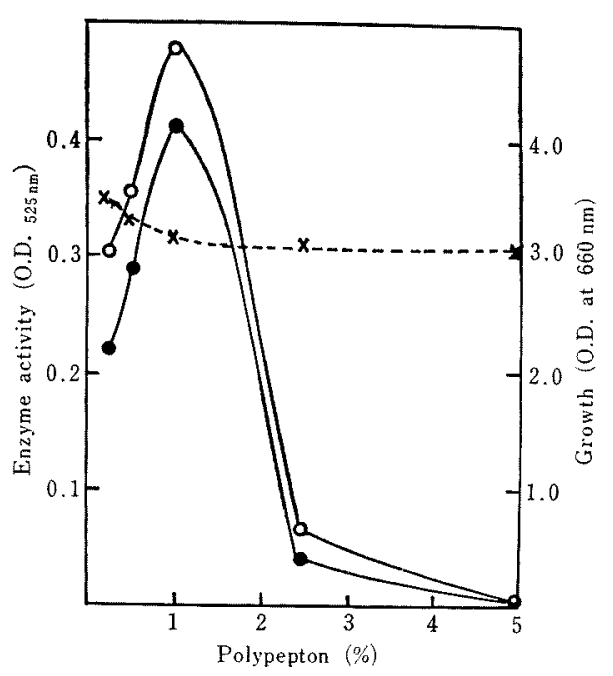

Frg. 4. Effect of Polypepton Concentration on Enzyme formation.

Incubations were carried out for $30 \mathrm{hr}$ at $30^{\circ} \mathrm{C}$ using $0.5 \%$ lactose as a carbon source.

$\times--\times$, Growth; $0-0$, Enzyme activity to CBZ-Lglutamine; - Enzyme activity to $t$-AOC-Lglutaminyl-L-proline.

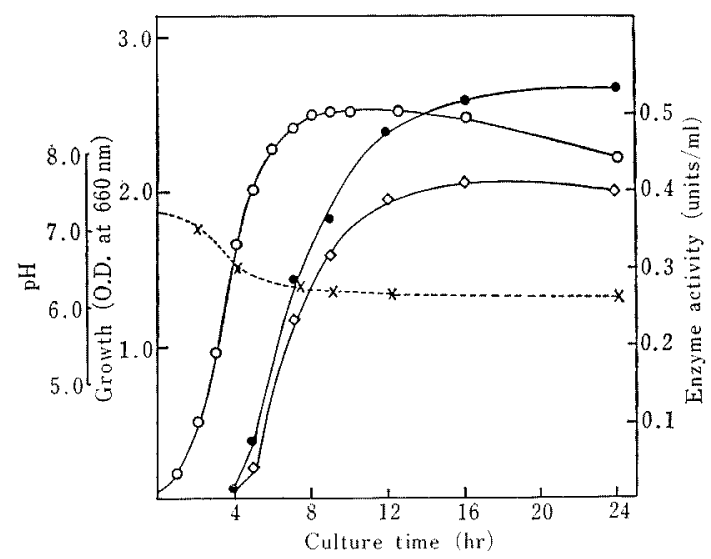

FIo. 5. Time Course of Enzyme Formation.

$0.5 \%$ Lactose and $1 \%$ polypepton were used as carbon and nitrogen sources, respectively.

$\mathrm{O}-\mathrm{O}$, Growth; -- Enzyme activity to CBZ-Lglutamine; $-\diamond$, Enzyme activity to $t$-AOC-Lglutaminyl-L-proline; $\times---\times$, pH.

$(1.0 \%)$ are presented in Fig. 5 . The detectable amount of enzyme formation was observed from exponential growth of cells at about $5 \mathrm{hr}$ and the enzyme yield per broth was the highest at 16 to $24 \mathrm{hr}$ cultivation. 
Acknowledgements. We are indebted to Professor S. Sakakibara and Dr. H. Hayashida for advice and for synthesizing peptides that were indispensable for this work. We are very grateful to Professors K. Arima and Y. Ikeda for valuable advice. The authors wish to acknowledge the helpful discussions with Dr. I. Koshiyama in preparation of this manuscript. The authors also thank Drs. M. Mogi and N. Iguchi for their encouragement and Mr. S. Kitahara for his help on electron micrograph. This work was supported in part by the Central Research Laboratories of Kikkoman Shoyu Co. Ltd.

\section{REFERENCES}

1) S. C. Hartman, J. Biol. Chem., 243, 853 (1968).

2) A. Meister, "Methods in Enzymology," Vol. II, 1955 , p. 380.

3) A. Meister, L. Levintow, R. E. Greenfield and
P. Abendshein, J. Biol. Chem., 215, 441 (1955)

4) E. Roberts, Enzymes, 4, 285 (1960).

5) M. J. Mycek and H. Waelsch, J. Biol. Chem. 235, 3513 (1960).

6) J. E. Folk and P. W. Cole, ibid., 240, 2951 (1965)

7) M. Kikuchi, H. Hayashida, E. Nakano and K Sakaguchi, Biochemistry, 10, 1222 (1971).

8) F. Lipmann and L. C. Tuttle, J. Biol. Chem. 159, 21, (1954).

9) F. Cedrangolo, F. Salvatore, F. Cimino and V. Zappia, Enzymologia., 29, 143 (1965).

10) M. J. Pelczar, Jr.; "Manual of Microbiological Methods," by the Society of American Bacteriologists, New York, N. Y., McGraw-Hill (1957).

11) R. S. Breed, E. G. D. Murray and N. R. Smith, "Bergey's Manual of Determinative Bacteriology," 7 th ed., Baltimore, Md., Williams \& Wilkins, p. 628 (1957). 